\title{
Hil
}

Volume 14 Issue 4 Year: 2017

\section{An investigation of ecocentric and anthropocentric attitudes and antipathy towards environment in athletes ${ }^{1}$}

\author{
Beyza Merve Akgül ${ }^{2}$ \\ Cenk Birinci ${ }^{3}$ \\ Şenol Göral ${ }^{4}$ \\ Suat Karaküçük ${ }^{5}$
}

\begin{abstract}
The aim of this study is to examine the ecocentric, anthropocentric and antipathetic attitudes towards the environment regarding with different variables. Study group is composed of 413 athletes randomly selected from directly nature sports and also sports that is not related to nature. To collect data, ecocentric, anthropocentric and antipathetic attitudes towards the protection of the environment scale is used. To analyze the data, descriptive statistics of the athletes' attitudes towards environment were calculated. For other variables' comparison, independent t-test and ANOVA were applied. As a result; amongst athletes' the ecocentric attitudes' mean was found the highest. Athletes' ecocentric attitude values vary only. According to their educational level; anthropocentric attitude values vary according to their sport type and educational level; antipathetic attitudes towards the protection of the environment vary according to sex, sports type, educational level, perceived income level and also the living environment. s conclusion; athletes with university and higher educational levels have higher ecocentric scores than athletes with high school and lower education levels; athletes from nature sports and athletes with high school and lower educational levels have higher anthropocentric scores than athletes from indoor sports and athletes with university and higher educational levels; finally, men participants than women participant, athletes from nature sports than athletes from indoor sports, athletes with high school and lower educational levels than athletes with university and higher educational levels, participants with high and low perceived income levels than participants with average perceived income levels, participants living in country side than participants living in cities have higher antipathetic attitude scores towards the protection of the environment.
\end{abstract}

Keywords: Athletes; environment; ecocentric attitude; anthropocentric attitude

\footnotetext{
1 This research was presented as oral presentation in International Sports Sciences Congress, ----th October 2016, Antalya/Turkey.

2 Associate Prof. Dr. Gazi University, Sport Science Faculty, Recreation Department, beyzakgulgazi@gmail.com

${ }^{3}$ Research Asistant. Gazi University, Tourism Faculty, Recreation Management Department, birincicenk@gmail.com

${ }^{4}$ Research Asistant.. Gazi University, Sport Science Faculty, Recreation Department, senolgoral@gmail.com

${ }^{5}$ Prof. Dr., Gazi University, Sport Science Faculty, Recreation Department, ksuat@gazi.edu.tr
} 
Akgül, M. B., Birinci, C., Göral, Ş., \& Karaküçük, S. (2017). An investigation of ecocentric and anthropocentric attitudes and antipathy towards environment in athletes. Journal of Human Sciences, 14(4), 3405-3414. doi:10.14687/ihs.v14i4.4680

\section{Introduction}

An insight into all beliefs and thoughts of a human being about existence and creation shows us that humans perceive the nature, which he can not fully comprehend, in two different ways, as either a system that he is a part of, or a resource that he will make use to maintain his existence. This means that two main contrasting attitudes against nature exist in all populations. These are ecocentric and anthropocentric attitudes. Ecocentric, or in other words, "naturecentered" attitude claims that the human is part of nature and natural life. On the other hand, anthropocentric, or "human-centered" attitude argues that human is the most important element that exists in this system and that all other things exist, or were created for serving him. According to this camp, the human is at the top of the life and food pyramid. Ecocentric attitude advocates the opposite. According to ecocentrism, the human has an equal value to all other living or nonliving things in nature, living in harmony with

them. No living or non-living being is superior or more valuable than others, and every element has vital significance for others.

Ecocentrism advocates that nature is independent of the human, exist fully on its own, and has an intrinsic value since existence; and in fact, it is not only a resource for humans to maintain their existence (Oelschlager, 1992). Supporters of this camp argue that industrialization and the modern life shaped by the industrial society trigger the perception that human beings are distinct and different from nature and natural life; that populations as a whole are alienated to nature and natural life, and became afraid of natural life and nature itself (Louv, 2008; Schultz, 2000, 2002; Brymer and Gray, 2010).

According to a predominant conventional view, nature itself is considered as a mature and precious opponent that we have to compete, fight, and overcome (Celsi et al, 1993; Rosenblatt, 1999; Millman, 2001; Brymar and Gray, 2010; Cocks and Simpson, 2015). This view against nature, and also the nature-human relationship that evolved in this way have alienated humans from nature and kept them away from natural habitats. Thus, humans have begun perceiving the nature as a concept that has to be feared and therefore, has to be harnessed (Stilgoe, 2001). Nature is either; a force that is left to human will for individual or social identity acquisition; or a living space for human populations with similar views; or a matured resource that humans can utilize to sustain his life; or a large and natural playground which humans are a part of by chance and exist within (Shoham et al, 2000).

The main argument that ecocentrism is based on is the view that humanity is a part of the nature (Davis, 1996; DeMares \& Krycka, 1998; Scull, 1999, Lundmark, 2007; Brymar and Gray, 2010). This means that, in contrast to the view that human beings are unique and most important beings in the universe and are superior to all other living and non-living existence, humans are only a part of nature as all other living beings (Williams \& Parkman, 2003). Ecocentric demeanor and attitude denies the argument that nature is a fighting arena or a playground, that should be perceived as a resource. Ecocentric attitude conceives nature as a very large family, and requires the individual perceive the nature as his/her own self, and see it as a whole and a unison (Glendinning, 1994; Watts, 1970). From this perspective, fighting with nature means fighting off the individual with himself. Attempts to understand the nature is indeed a reflection of human's intent to understand and analyze himself and his existence in nature.

Anthropocentrism, on the other hand, is based on the view that human species, his life, and his existence are superior to every other thing in nature, and that all elements related to nature exist for his own existence.

From a materialistic and anthropocentric point of view, the Earth and nature are creations whose sole purpose of existence is to serve humankind, therefore they are regarded as "alterity" (Mathews, 2006). Some scientists describe ecocentric and anthropocentric demeanors and attitudes as intellectual and philosophical counterparts of environmentalism and conservatism concepts that we frequently hear in our daily life. If we are to evaluate anthropometric demeanor and attitude 
Akgül, M. B., Birinci, C., Göral, Ș., \& Karaküçük, S. (2017). An investigation of ecocentric and anthropocentric attitudes and antipathy towards environment in athletes. Journal of Human Sciences, 14(4), 3405-3414. doi:10.14687/ihs.v14i4.4680

from such a perspective, then we conclude that the most precious species and being found in nature should be human. In that sense, nature with all its components is as valuable as it is beneficial to human species and human life (Casas \& Burgess, 2012). Kronlid and Öhman (2013), discussed these attitudes with more philosophical standpoint and brought more comprehensive interpretations on ecocentric and anthropocentric attitudes. Kronlid and Öhman(2013) warn their readers against perceiving anthropocentric attitude as "non-environment friendly" or "antienvironment" demeanor or perceiving all kinds of non-anthropocentric thoughts as "environmentfriendly" demeanor. Although some behavior with destructive environmental results can be related to anthropocentric attitudes, it would not be accurate if we are to claim that the only motive behind the destructive behavior is an anthropocentric way of thinking. That is to say, if we interpret anthropocentric attitude in a way that "nature is valuable because it is beneficial for humans and human life", and at the same time if we plant the idea that nature and outdoor activities are excellent hobbies with physical and mental benefits to humans, either vaguely or overtly in recreation educations, then we inevitably promote anthropocentrism to these students (Cocks \& Simpson, 2015).

Should we protect the nature for its own sake, or because of material benefits it can provide for humans? This study gives a clue to understanding what thought lies behind athletes' motive to protect nature. A human who thinks nature should be protected for its own sake can be expected to act in favor of nature. On the other hand, those who believe that nature should be protected for better life quality are self-seekers. The reason behind man's slaughtering or attempting to kill many animals with a mindset like "what's its benefit to us?" is the psychological factor based on the anthropocentric way of thinking. People with such demeanors protect nature as long as their interests are met, and there is a direct relationship between continuity of interests and protection of nature. The aim of this study is to evaluate attitudes of athletes from different branches towards the environment in three categories as eco-centric (nature-centered), anthropocentric (human-centered) and antipathy towards protection of nature, and to analyze these attitudes according to some variables.

\section{Method}

\section{Study group}

The study group is comprised of 413 athletes randomly selected from among outdoor athletes and athletes from various branches in Turkey. Of these athletes, 216 were performing nature sports (56\% skiing, 46\% orienteering), whereas 197 were performing other branches of sports ( $45 \%$ football, $22 \%$ volleyball, $43 \%$ fitness)( Table 1 ).

Table 1: Demographics of the Students $(\mathrm{N}=413)$

\begin{tabular}{llll}
\hline \multirow{2}{*}{ Gender } & & $\mathrm{N}$ & $\%$ \\
\hline \multirow{3}{*}{ Education level } & Female & 180 & 44 \\
\cline { 2 - 4 } & Male & 233 & 56 \\
& $\begin{array}{l}\text { High school and } \\
\text { below }\end{array}$ & 211 & 51 \\
\cline { 2 - 4 } & $\begin{array}{l}\text { Undergraduate } \\
\text { above }\end{array}$ & 202 & 49 \\
\hline \multirow{3}{*}{ Income } & Low & 97 & 23 \\
\cline { 2 - 4 } & Moderate & 216 & 52 \\
\hline \multirow{2}{*}{ Living Place } & High & 110 & 25 \\
\cline { 2 - 4 } & Rural area & 61 & 15 \\
\hline Urban area & 192 & 47 \\
\cline { 2 - 4 } $\begin{array}{l}\text { Branch of } \\
\text { sports }\end{array}$ & Metropol & 160 & 38 \\
\hline & Nature Sports & 216 & 52 \\
\cline { 2 - 4 } & Others & 197 & 48 \\
\hline
\end{tabular}


Akgül, M. B., Birinci, C., Göral, Ş., \& Karaküçük, S. (2017). An investigation of ecocentric and anthropocentric attitudes and antipathy towards environment in athletes. Journal of Human Sciences, 14(4), 3405-3414. doi:10.14687/jhs.v14i4.4680

\section{Data Collection Tool}

As data collection tool, "Ecocentric, Anthropocentric, and Antipathetic Environmental Attitudes Scale" was used. This scale was developed by Thompson and Barton (1994), and it was later adapted to German by Siegrist (1996), and to Turkish by Erten (2007). There are 11 items for ecocentric attitude, 8 items for anthropocentric attitude, and 7 items for antipathetic attitude. The questionnaire is a seven-point Likert-type scale ranging from "strongly disagree" to "strongly agree". In the study by Thompson and Barton (1994), Cronbach's $\alpha$ value was $\alpha=.77$ for ecocentric attitudes, $\alpha=.78$ for anthropocentric attitudes and $\alpha=.92$ for antipathetic attitude towards protection of environment; whereas in Siegrist's(1996) adaptation study, Cronbach's $\alpha$ value was $\alpha$ $=.82$ for ecocentric attitude, $\alpha=.72$ for anthropocentric attitude, and $\alpha=.74$ for antipathetic attitude towards protection of environment. In this study, Cronbach's $\alpha$ value was $\alpha=.77$ for ecocentric attitudes, $\alpha=.77$ for anthropocentric attitudes and $\alpha=.95$ for antipathetic attitude towards protection of the environment.

\section{Data Analysis}

During data collection step, sports clubs were interviewed, and athletes volunteering to participate in the study were informed about the study and the questionnaire by researchers. Frequency and percentage calculations were carried out for demographical properties of the study group. Distributions of variables according to groups were examined, the normality of the distributions and homogeneity of variances were evaluated, and distributions were observed to display parametric feature. Data regarding athletes' attitude towards environment was expressed in descriptive statistics. Comparisons for other variables were made with independent single sample ttest and one-way analysis of variance .

\section{Results}

This section presents results regarding athletes' eco-centric, anthropocentric attitudes and antipathy towards protection of the environment; and results of comparisons between various variables.

Table 2. Athletes' Mean And Standard Deviations For The Ecocentric, Anthropocentric And Antipathetic Attitudes Towards Protection Of The Environment

\begin{tabular}{lllll}
\hline \multicolumn{1}{c}{$\mathrm{N}=(413)$} & \multicolumn{5}{l}{} \\
\cline { 2 - 5 } & $\bar{x}$ & ss & Min & Max. \\
\hline Ecocentric Attitude & 64.95 & 7.44 & 34.00 & 77.00 \\
\hline Antropocsentric Attitude & 46.28 & 6.66 & 16.00 & 56.00 \\
\hline Antipathetic Attitude & 27.91 & 14.08 & 7.00 & 49.00 \\
\hline
\end{tabular}

Table 3. Comparison Of Athletes' Ecocentric, Antropocentric And Antipathetic Attitudes Scores According To Branch Of Sports

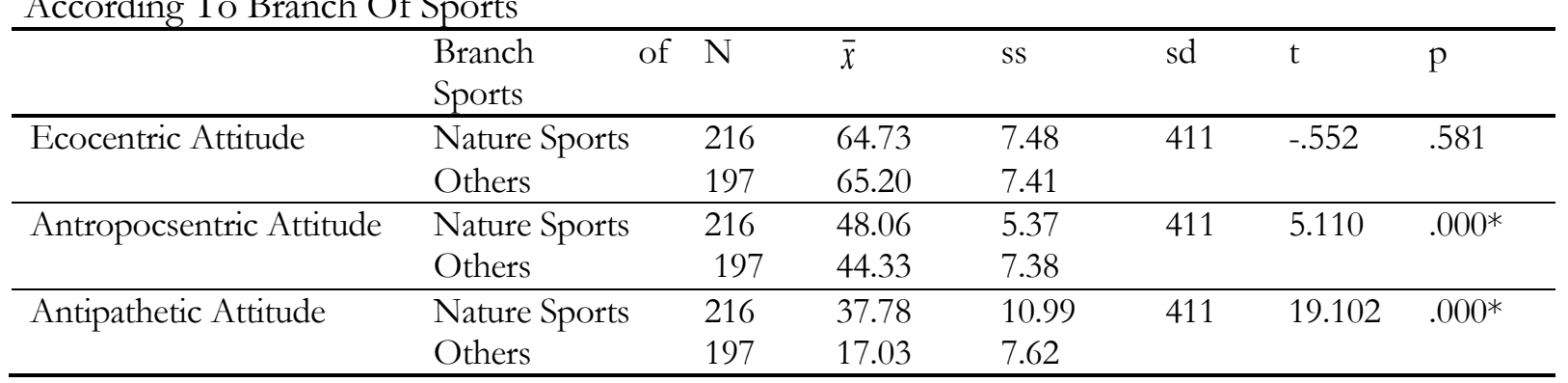

${ }^{*} \mathrm{p}<.05$ 
Akgül, M. B., Birinci, C., Göral, Ş., \& Karaküçük, S. (2017). An investigation of ecocentric and anthropocentric attitudes and antipathy towards environment in athletes. Journal of Human Sciences, 14(4), 3405-3414. doi:10.14687/ihs.v14i4.4680

Ecocentric, anthropocentric and antipathetic attitudes of athletes towards environment were compared between different branches of sports using t-test. Accordingly, anthropocentric and antipathetic attitudes vary between different branches of sports $(p<.05)$. Anthropocentric and antipathetic attitude scores of athletes performing nature sports were higher compared to athletes of other branches( Table 3).

Table 4. Comparison Of Athletes' Ecocentric, Antropocentric And Antipathetic Attitudes Scores According To Gender

\begin{tabular}{llllllll}
\hline & Gender & $\mathrm{N}$ & $\bar{x}$ & $\mathrm{ss}$ & $\mathrm{sd}$ & $\mathrm{t}$ & $\mathrm{p}$ \\
\hline Ecocentric Attitude & Male & 233 & 64.91 & 7.83 & 411 & -.112 & .911 \\
& Female & 180 & 65.01 & 6.88 & & & \\
\hline Antropcsentric Attitude & Male & 233 & 46.07 & 6.82 & 411 & -.657 & .511 \\
& Female & 180 & 46.58 & 6.43 & & & \\
\hline Antipathetic Attitude & Male & 233 & 29.57 & 14.03 & 411 & 2.483 & $.014^{*}$ \\
& Female & 180 & 25.56 & 13.87 & & & \\
\hline
\end{tabular}

${ }^{*} \mathrm{p}<.05$

Ecocentric, anthropocentric and antipathetic attitudes of athletes towards environment were compared between the sexes using t-test. Accordingly, antipathetic attitudes vary between the sexes of athletes $(p<.05)$. Female athletes had lower scores of antipathetic attitude toward environment compared to male athletes( Table 4).

Table 5. Comparison Of Athletes' Ecocentric, Antropocentric And Antipathetic Attitudes Scores According To Education Level

\begin{tabular}{llllllll}
\hline & Education level & $\mathrm{N}$ & $\bar{x}$ & $\mathrm{ss}$ & $\mathrm{sd}$ & $\mathrm{t}$ & $\mathrm{p}$ \\
\hline Ecocentric Attitude & $\begin{array}{l}\text { High school and } \\
\text { below }\end{array}$ & 211 & 62.89 & 7.59 & 411 & -5.229 & $.000^{*}$ \\
& $\begin{array}{l}\text { Undergraduate } \\
\text { and above }\end{array}$ & 202 & 67.14 & 6.63 & & & \\
\hline Antropcsentric Attitude & $\begin{array}{l}\text { High school and } \\
\text { below }\end{array}$ & 211 & 47.04 & 5.81 & 411 & 2.065 & $.040^{*}$ \\
& $\begin{array}{l}\text { Undergraduate } \\
\text { and above }\end{array}$ & 202 & 45.48 & 7.39 & & & \\
\hline Antipathetic Attitude & $\begin{array}{l}\text { High school and } \\
\text { below }\end{array}$ & 211 & 33.99 & 12.08 & 411 & 8.715 & $.000^{*}$ \\
& $\begin{array}{l}\text { Undergraduate } \\
\text { and above }\end{array}$ & 202 & 21.46 & 13.19 & & & \\
\hline
\end{tabular}

${ }^{*} \mathrm{p}<.05$

Ecocentric, anthropocentric and antipathetic attitudes of athletes towards environment were compared between different education levels of athletes using t-test. Accordingly, eco-centric, anthropocentric and antipathetic attitudes vary between different education levels of athletes $(p<.05)$. Athletes who had bachelor's degree or higher education level had higher ecocentric attitude scores than those having a lower education level, whereas athletes who were high school graduates or had lower education level had higher anthropocentric and antipathetic attitude scores than those having a bachelor's degree or higher education level( Table 5). 
Akgül, M. B., Birinci, C., Göral, Ș., \& Karaküçük, S. (2017). An investigation of ecocentric and anthropocentric attitudes and antipathy towards environment in athletes. Journal of Human Sciences, 14(4), 3405-3414. doi:10.14687/ihs.v14i4.4680

Table 6. Comparison Of Athletes' Ecocentric, Antropocentric And Antipathetic Attitudes Scores According To Perceived Income

\begin{tabular}{lllllll}
\hline & Income & $\mathrm{N}$ & $\bar{x}$ & ss & $\mathrm{F}$ & $\mathrm{p}$ \\
\hline Ecocentric Attitude & Low & 97 & 65,40 & 7,49 & 0,92 & 0,39 \\
& Medium & 216 & 64,46 & 7,70 & & \\
& High & 110 & 65,75 & 6,76 & & \\
Antropocsentric & Low & 97 & 46,72 & 5,00 & 2,90 & 0,05 \\
Attitude & Medium & 216 & 45,54 & 7,08 & & \\
& High & 110 & 47,67 & 6,57 & & \\
Antipathetic Attitude & Low & 97 & 31,63 & 12,68 & 6,11 & $0,00^{*}$ \\
& Medium & 216 & 25,53 & 13,78 & & \\
& High & 110 & 30,63 & 14,84 & & \\
\hline
\end{tabular}

$* \overline{\mathrm{p}}<.05$

Ecocentric, anthropocentric and antipathetic attitudes of athletes towards environment were compared according to their perceived income levels using ANOVA test. Accordingly, antipathetic attitudes vary between different income levels of athletes $(p<.05)$. In order to determine which groups caused the difference, Tukey test was performed. According to the results, athletes perceiving their income level as high and low had higher antipathetic attitude scores than those perceiving their income level as moderate (Table 6).

Table 7. Comparison Of Athletes' Ecocentric, Antropocentric And Antipathetic Attitudes Scores According To Living Place

\begin{tabular}{lllllll}
\hline & Living Place & $\mathrm{N}$ & $\bar{x}$ & ss & $\mathrm{F}$ & $\mathrm{p}$ \\
\hline Ecocentric Attitude & Rural Area & 61 & 66,07 & 4,23 & 0,79 & 0,45 \\
& Urban Area & 192 & 64,47 & 7,95 & & \\
& Metropol & 160 & 65,13 & 7,66 & & \\
Antropocsentric & Rural Area & 61 & 47,80 & 3,74 & 1,37 & 0,25 \\
Attitude & Urban Area & 192 & 46,25 & 7,15 & & \\
& Metropol & 160 & 45,83 & 6,79 & & \\
Antipathetic Attitude & Rural Area & 61 & 38,12 & 9,78 & 25,54 & $0,00^{*}$ \\
& Urban Area & 192 & 29,90 & 14,41 & & \\
& Metropol & 160 & 22,34 & 12,42 & & \\
\hline
\end{tabular}

$* \overline{\mathrm{p}<.05}$

Ecocentric, anthropocentric and antipathetic attitudes of athletes towards environment were compared according to the place they live using ANOVA test. Accordingly, antipathetic attitudes vary according to athletes' area of living $(\mathrm{p}<.05)$. Tukey test was performed to determine which groups caused the difference; and according to the results, athletes spending most of their lives in an urban setting had lower antipathetic attitude scores than those living in a rural area, and those spending most of their lives in a metropolis had lower antipathetic attitude scores than those living in urban and rural areas( Table 7). 
Akgül, M. B., Birinci, C., Göral, Ş., \& Karaküçük, S. (2017). An investigation of ecocentric and anthropocentric attitudes and antipathy towards environment in athletes. Journal of Human Sciences, 14(4), 3405-3414. doi:10.14687/ihs.v14i4.4680

\section{Discussion}

The aim of this study is to evaluate demeanors of athletes from different branches towards environment under three groups of attitudes as eco-centric (nature-centered), anthropocentric (human-centered) and antipathy towards protection of the environment, and to examine these attitudes according to some variables. According to our results, athletes' demeanors towards environment was found to be nature-centered in general; however, athletes performing nature sports had higher anthropocentric and antipathetic attitude scores compared to athletes from other branches. This is an expected result for individuals with higher environmental awareness, because an individual with nature-centered attitude does not prioritize human interest in environmental issues, he does not categorize nature or living things in nature based on their benefit to the humankind, but rather sees them as indispensable parts of the nature, and believes at heart that they should be protected for their own sake. Although nature-centered attitude is the desired condition, human-centered attitudes is not an expected condition. Because origins of human-centered attitude involves thoughts based on human interest. People with this option protect their environment as far as they have interests. People with materialistic thought represent human-centered thought (anthropocentric), while abstract thinkers represent nature-centered (ecocentric) thought. Individuals with human-centered thought also have a moral value of nature because either harming or protecting the nature will return back as harm or benefit to the human kind.

Another finding of the present study is that female athlete had lower scores of antipathetic attitude toward environment compared to male athletes. There are many studies in support of this finding. Karakaya and Çobanoğlu (2009) found that attitudes of students toward nature varied according to their gender. Female students were found to have higher mean scores of attitude towards environment compared to male students. This indicates that female students are closer to nature-centered demeanors compared to male students. This finding may be thought to reflect the fact that females are raised in more affectionate, nurturing and conservative way compared to males. In other words, since the nature-centered way of thinking is an effective property, this finding can be explained by the fact that females have higher emotional intelligence compared to males. As stated by Tuğrul (1999), families' demeanor towards developing their child's emotional intelligence vary according to child's gender; and there is generally more positive approach towards females. There are numerous studies that state females have more nature-oriented, eco-centric, and positive demeanor/behavior/interest/perspectives compared to males (Casey \& Scott, 2006; Şama, 2003; Tuncer et al. 2009; Yücel et al., 2006). Casey \& Scott (2006) concluded that females had more positive environmental interests and behaviors compared to males, and they tried to explain this by the fact that females are traditionally given more affectionate, nursing social roles.

Tikka et al. (2000) concluded that females approached the nature in a more responsible way compared to males, and they attributed this difference to males' approach to utilization of nature and natural resources and females' more emotional approach towards nature. Studies have shown that sex is influential on environmental attitude, that females are much more interested in environmental issues compared to males and have more positive attitude, supporting the results of the present study (Alp et al. 2006; Hacieminoğlu et al. 2006; Uzun 2005; Ekici 2005; Yllmaz et al. 2004; Şama 2003; Paraskevopoulos et al. 2003; Tikka, et al. 2000) eported that females are more sensitive in environmental issues and that they believed environmental sustainability and protection have great importance for the future.

According to our results, athletes who had bachelor's degree or higher education level had higher ecocentric attitude scores than those having a lower education level, whereas athletes who were high school graduates or had lower education level had higher anthropocentric and antipathetic attitude scores than those having a bachelor's degree or higher education level. Activities related to environmental education, public discussions about environmental issues within recent years in Turkey, and related discussions in the media have been effective to achieve this result. Students generally have nature-centered attitudes, which may be because they have a certain 
Akgül, M. B., Birinci, C., Göral, Ş., \& Karaküçük, S. (2017). An investigation of ecocentric and anthropocentric attitudes and antipathy towards environment in athletes. Journal of Human Sciences, 14(4), 3405-3414. doi:10.14687/ihs.v14i4.4680

level of knowledge towards environmental issues, and therefore a certain level of sensitivity in this regard. For this reason, it is very important that education programs should aim to change people's perspective on nature, shaping their values and attitudes in order to prevent environmental problems (Hungerford and Peyton, 1976)

Ecocentric, anthropocentric and antipathetic attitudes of athletes towards environment varied according to perceived income levels. Accordingly, athletes perceiving their income level as high and low had higher antipathetic attitude scores than those perceiving their income level as moderate. Studies have shown that income level is influential on attitude towards environmental issues (Yilmaz et al. 2004; Şama 2003; Uyeki and Holland 2000; Thompson and Gasteiger 1985). This is related to consumption habits. Since people with higher income level spend more, this can cause a negative demeanor in terms of environment. On the other hand, environmental issues do not have much importance for people with low income.

Ecocentric, anthropocentric and antipathetic attitudes of athletes towards environment varies according to the place they live. Athletes spending most of their lives in an urban setting had lower antipathetic attitude scores than those living in a rural area, and those spending most of their lives in a metropolis had lower antipathetic attitude scores than those living in urban and rural areas. There are numerous studies in literature related to environmental attitudes (Hacieminoğlu et al 2006; Ekici 2005; Uzun 2005; Yllmaz et al, 2004; Sama 2003; Uljas 2001; Kilbourne et al, 2001; Pooley and O'Connor 2000). However, we did not encounter studies that examined attitudes under these three titles. Tuncer et al (2004) studied environmental attitudes of 6th-grade students from urban and rural areas of Ankara, Turkey. They found a significant difference between environmental attitudes of students from urban and rural areas. Their results were in parallel with the results of the present study. Yilmaz et al. (2004) found that those who lived in urban areas had more positive environmental attitude compared to those from rural areas. The higher sensitivity towards environmental issues may be related to their discomfort with existing environmental issues that they experience. This result was consistent with the results of Karakaya and Çobanoğlu(2012). They stated that, considering that among these students with nature-centered demeanors, minority $(12 \%)$ were from natural environments such as villages and others $(88 \%)$ were from urban areas such as towns, cities and metropolises, the place of living had an influence on their attitudes. As stated by Atasoy (2005), one of the main purposes of environmental education is to teach looking to nature from an environment-centered perspective, i.e., ecological standpoint, and therefore, train them to fight for the environment.

Yslmaz et al. (2004) reported that environmental attitude was more positive among females compared to males; students with higher success compared to lower success; students with higher family income compared to those with lower family income; students living in urban areas compared to those living in rural areas.

\section{Recommendations}

In order to become an environment-friendly society with environmental awareness, we should at once start environmental education studies to raise individuals with the environmentally oriented mindset, before we give more harm to the environment. Students' lack of any positive development regarding environment-friendly demeanor may be interpreted as a lack of internalization of the environmental education and reflection of this knowledge to their daily life and activities, or this may be due to various reasons including economic and environmental factors as well. However, since this subject requires detailed research, investigation, and analysis, it was not examined within the context of the present study. To improve nature-centered attitudes and therefore, environmental awareness, the basic starting point should be familiarizing with plants and animals, fostering interest in them, and eliminating aggression and phobias towards animals. In order to reflect these perspectives to practice, sports sciences faculties should conduct natureoriented activities. Various recreational programs should be established, and common activities 
Akgül, M. B., Birinci, C., Göral, Ş., \& Karaküçük, S. (2017). An investigation of ecocentric and anthropocentric attitudes and antipathy towards environment in athletes. Journal of Human Sciences, 14(4), 3405-3414. doi:10.14687/ihs.v14i4.4680

should be arranged with the help of non-governmental organizations. These recreational activities should educate people on environmental awareness. Establishment of related student organizations should be promoted, with the aim of increasing the number of outdoor activities. Additionally, there may be practices that will aid the students to keep these views and transfer them to their future students once they become a teacher. Students can be informed about the risks of increased population and importance of population planning, at such times when environmental issues are growing progressively, and these educations can be given in various ways.

Female students are statistically more oriented towards nature-centered attitudes compared to male students. In order to enhance environment-friendly attitude in males, more tasks and responsibilities can be given to them during activities related to environment and nature.

\section{References}

Alp, E., Ertepınar, H., Tekkaya, C. ve Yılmaz, A. (2006). İlköğretim öğrencilerinin çevreye yönelik tutum ve bilgileri üzerine bir çalş̧ma. VII. Ulusal Fen Bilimleri ve Matematik Eğitimi Kongresi Öz̧etler Kitabı. (ss.110). (07-09 Eylül 2006). Ankara: Palme Yayıncilık.

Brymer, E. \& Gray, T. (2010) Developing an intimate "relationship" with nature through extreme sports participation, Leisure/Loisir, 34:4, 361-374, DOI: 10.1080/14927713.2010.542888

Casas, A. B., \& Burgess, R. A. (2012). The practical importance of philosophical inquiry for environmental professionals: A look at the intrinsic/instrumental value debate. Environmental Practice: Journal of the National Association of Environmental Professionals, 14(3), 184-189

Casey, P. J., \& Scott, K. (2006). Environmental concern and behaviour in an Australian sample within an ecocentric-anthropocentric framework. American Journal of Psychology, 58(2), 57-67.

Celsi, R.L., Rose, R.L., \& Leigh, T.W. (1993). An exploration of high-risk leisure consumption through skydiving. Journal of Consumer Research, 20, 1-23

Cocks, S. \& Simpson, S. (2015). Anthropocentric and Ecocentric: An Application of Environmental Philosophy to Outdoor Recreation and Environmental Education. Journal of Experiential Education, SagePub, Vol. 38(3) 216-227

Davis, J. (1996). An integrated approach to the scientific study of the human spirit. In B.L. Driver, D. Dustin, T. Baltic, G. Elsner, \& G. Peterson (Eds.), Nature and the human spirit: Toward an expanded land management ethic (pp. 417-429). State College, PA: Venture Publishing.

DeMares, R., \& Krycka, K. (1998). Wild-animal-triggered peak experiences: Transpersonal aspects. The Journal of Transpersonal Psychology, 30(2), 161-177.

Ekici, G. (2005). Lise öğrencilerinin çevre eğitimine yönelik tutumlarının incelenmesi. Eğitim Araşttrmalarr. 18, $71-83$

Erten, S. (2007). Ekosentrik, antroposentrik ve çevreye yönelik antipatik tutum ölçeğinin Türkçeye uyarlama çalsşmasi. Eurasian Journal of Education Research, 28, 67-74.

Gardos, V. \& Dodd, D. (1995). An immediate response to environmentally disturbing news and the enviroenmental attitudes of college students. Psychological Reports, 77, 1121-1122.

Glendinning, C. (1994). My name is Chellis \& I'm in recovery from western civilization. Boston, MA: Shambhala.

Hacıeminoğlu, E., Alp, E. ve Ertepınar, H. (2006). Öğretmen adaylarının çevreye ve çevre konularını öğretmeye yönelik tutumları. VII. Ulusal Fen Bilimleri ve Matematike Ë̆gitimi Kongresi Özettler Kitabı. (ss.113). (07-09 Eylül 2006). Ankara: Palme Yayıncilik.

Hungerford, R. H. \& Peyton, R. B. (1976). Teaching environmental education. Portland, ME: J. Weston Walch. In Hsu, Shih-Jang. (2004). The effects of an environmental education program on responsible environmental behavior and associated environmental literacy variables in Taiwanese college students. The Journal of Environmental Education, 35(2): 37-48.

Karakaya, Ç.\& Çobanoğlu, EO. (2012). İnsanı Merkeze Alan(Antroposentrik) Ve Almayan (Nonantroposentrik) Yaklaşımlara Göre Eğitim Fakültesi Son Sınıf Öğrencilerinin Çevreye Yönelik Bakış Açıları, Türk Fen eğitimi Dergisi, 9(3), 23-35.

Kronlid, D. O., \& Öhman, J. (2013). An environmental ethical conceptual framework for research on sustainability and environmental education. Environmental Education Research, 19(1), 21-44. 
Akgül, M. B., Birinci, C., Göral, Ş., \& Karaküçük, S. (2017). An investigation of ecocentric and anthropocentric attitudes and antipathy towards environment in athletes. Journal of Human Sciences, 14(4), 3405-3414. doi:10.14687/ihs.v14i4.4680

Louv, R. (2008). Last child in the woods: Saving our children from nature-deficit disorder. Chapel Hill, NC: Algonquin.

Lundmark, C. (2007). The new ecological paradigm revisited: Anchoring the NEP scale in environmental ethics. Environmental Education Research, 13(3), 329-347.

Mathews, F. (2006). Beyond modernity and tradition: A third way for development? Ethics and the Environment, 11(2), 85-113

Millman, J. (2001). Extreme sports: Dudes vs. nature. Salon. Retrieved May 4, 2001, from www.salon.com/weekly/extreme960603.html (Akt: Brymer, E. ve Gray,T., 2010)

Oelschlaeger, M. (1992). Introduction. In M. Oelschlaefer (Ed.), The wilderness condition: Essays on environment and civilization (pp. 1-20). San Francisco, CA: Sierra Club Books.

Rosenblatt, R. (1999). "The whole world is jumpable": The most extreme sport of all often kills its players. What is its strange appeal? Time, 154(3), 94

Schultz, P.W. (2000). Empathizing with nature: The effects of perspective taking on concern for environmental issues. Journal of Social Issues, 56(3), 391-406

Schultz, P.W. (2002). Inclusion with nature: The psychology of human-nature relations. In P. Schmuck \& P.W. Schultz (Eds.), Psychology of sustainable development (pp. 61-78). Boston, MA: Kluwer Academic (Akt: Brymer, E. ve Gray,T., 2010)

Scull, J. (1999). Ecopsychology: Where does it fit in psychology. Retrieved February 24, 2004, from http://members.shaw.ca/jscull/ecointro.htm (Akt: Brymer, E. ve Gray,T., 2010)

Shoham, A., Rose, G.M., \& Kahle, L.R. (2000). Practitioners of risky sports: A quantitative examination. Journal of Business Research, 47, 237-251

Siegrist, M. (1996): Fragebogen zur erfassung der ökozentrischen und anthropozentrischenumwelteinstellung. Zeitschrift für Sozialpsychologie, 27,290-294.

Stilgoe, J.R. (2001). Gone barefoot lately. American Journal of Preventive Medicine, 20(3), 243-244.

Şama, E. (2003). Öğretmen adaylarının çevre sorunlarına yönelik tutumları. Gaæi Üniversitesi Gaæ̣ Eğitim Fakïltesi Dergisi, 23 (2): 99-110.

Thompson, S.C.G. \& Barton, M.A. (1994). Ecocentric and anthrocentric attitudes toward the environment. Journal of Environmental Pschology, 14,149-157.

Thompson, J. C. \& Gasteiger, E. L. (1985). Environmental attitude survey of university students 1971 vs 1981. ERIC No. ED 257648.

Tikka, P. M., Kuitunen, T. M., \& Tynys, M. S. (2000). Effects of educational background on students' attitudes, activity levels, and knowledge concerning environment. The Journal of Environmental Education, 31, 12-19.

Tuğrul, C. (1999). Duygusal zeka. Klinik Psikiyatri, 1, 12-20. (12.08.2009, http://www.klinikpsikiyatri.org/files/journals/1/21.pdf)

Tuncer, G., Tekkaya, C., Sungur, S., Çakıroğlu, J., Ertepınar, H., \& Kaplowitz, M. (2009). Assessing preservice teachers' environmental literacy in Turkey as a mean to develop Karakaya \& Cobanoğh I TUSED / 9(3) 201235

Uyeki, E. S. \& Holland, L. J. (2000). Diffusion of pro-environment attitudes? American Behavioral Scientist, 43(4), 646-662.

Uzun, N., \& Sağlam, N. (2006). Ortaöğretim öğrencileri için çevresel tutum ölçeği geliştirme ve geçerliliği. Hacettepe Üniversitesi Eğitim Fakïltesi Dergisi, 30, 240-250.

Watts, A. (1970). Nature, man and woman. New York, NY: Vintage Books

Williams, J., \& Parkman, S. (2003). On humans and environment: The role of consciousness in environmental problems. Human Studies, 26, 449-460

Yllmaz, O., Boone, W. \& Andersen, H. O. (2004). Views of elementary and middle school Turkish students toward environmental issues. International Journal of Science Education. 26(12): 1527-1546.

Yücel, M., Altunkasa, F., Güçray, S., Uslu, C., \& Say, N. P. (2006). Adana'da çevre duyarlllığ1 düzeyinin ve geliştirme olanaklarının araştırlması. Akedeniz Üniversitesi Ziraat Fakïltesi Dergisi, 19(2), 217-228. 